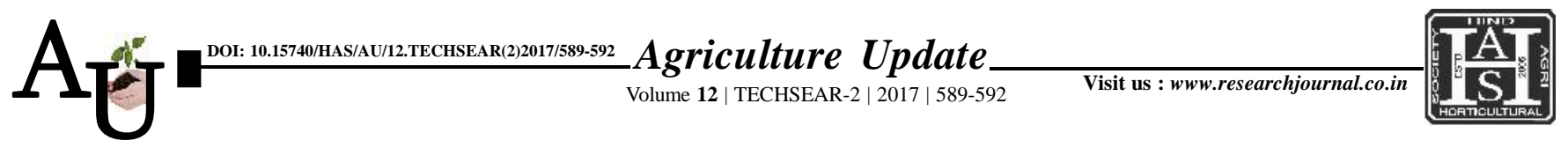

— e ISSN-0976-6847

\title{
Research article: Genetic diversity for yield, its contributing characters in rice (Oryza sativa L.)
}

\section{K. SUPRIYA, S. VANISRI, R. JAGADEESWAR AND M. SREEDHAR}

Article Chronicle: Received :

12.07.2017;

Accepted :

25.07.2017

KEY Words :

Cluster analysis, Genetic diversity, Alpha lattice design

Author for correspondence :

\section{K. SUPRIYA}

Department of Genetics and Plant Breeding, College of Agriculture, Professor Jayashankar Telangana State Agricultural University, Rajendranagar, HYDERABAD (TELANGANA) INDIA

Email : supriya.kamera@ gmail.com

See end of the article for authors' affiliations
SUMMARY : A set of 48 rice genotypes were subjected to Mahalanobis $\mathrm{D}^{2}$ analysis to assess the genetic diversity. All these genotypes were grouped into seven clusters with maximum inter cluster distance between cluster IV and cluster VII (55.28) and minimum inter cluster distance between cluster II and cluster IV (16.14). Among the eleven characters studied 1000 grain weight contributed maximum towards genetic divergence $(51.77 \%)$ followed by days to 50 per cent flowering $(35.55 \%)$ and days to maturity $(7.89 \%)$.

How to cite this article : Supriya, K., Vanisri, S., Jagadeeswar, R. and Sreedhar, M. (2017). Genetic diversity for yield, its contributing characters in rice (Oryza sativa L.). Agric. Update, 12(TECHSEAR-2) : 589-592; DOI: 10.15740/HAS/AU/12.TECHSEAR(2)2017/589-592. 